\title{
Spindle Cell Lipoma of the Oral Cavity: A Clinico-Pathologic Analysis of 35 Reported Cases ${ }^{*}$
}

\author{
Esther Manor ${ }^{1}$, Netta Sion-Vardy ${ }^{2}$, Peter A. Brennan ${ }^{3}$, Lipa Bodner ${ }^{4 \#}$ \\ ${ }^{1}$ Institute of Human Genetics, Soroka Medical Center, Faculty of Health Sciences, \\ Ben-Gurion University of the Negev, Beer-Sheva, Israel \\ ${ }^{2}$ Department of Pathology, Soroka Medical Center, Faculty of Health Sciences, \\ Ben-Gurion University of the Negev, Beer-Sheva, Israel \\ ${ }^{3}$ Department of Oral and Maxillofacial Surgery, Queen Alexandra Hospital, Portsmouth, UK \\ ${ }^{4}$ Department of Oral and Maxillofacial Surgery, Soroka Medical Center, Faculty of Health Sciences, \\ Ben-Gurion University of the Negev, Beer-Sheva, Israel \\ Email: "\#bodner@bgu.ac.il
}

Received January 21, 2013; revised February 24, 2013; accepted March 5, 2013

\begin{abstract}
Spindle-cell lipoma (SCL) is a variant of lipoma, usually presenting in the neck or trunk. SCL of the oral cavity is rare. Some cases of oral SCL have been reported; however, the clinico-pathologic characteristics of oral SCL are still unknown. Here we report on 2 cases and review 33 cases of oral SCL published in the literature. The patients were 23 men and 12 women, with a mean age of 55 years (range 23 - 88 years); there were no children. Tumor sites included: tongue $(n=13)$, cheek/buccal mucosa $(n=11)$, floor of mouth $(n=5)$, lip $(n=2)$, hard palate $(n=2)$, alveolar ridge $(n=1)$, and maxilla $(\mathrm{n}=1)$. The mean tumor size was $20.87 \mathrm{~mm}$ (range $3-50 \mathrm{~mm}$ ), smaller than extra-oral lesions. Thirty-three patients (94\%) presented with a single lesion that was circumscribed and composed of mature adipocytes admixed with bland spindle cells. The spindle cells were strongly immunoreactive for CD34, whereas the adipocytes were negative. The main differential diagnosis is atypical lipoma/well-differentiated liposarcoma. All lesions underwent local excision and recurrences are rare. Oral SCL do not seem to differ from their extra-oral counterpart, which are much more common and larger in size. SCL should be included in the differential diagnosis of oral cavity mesenchymal tumors.
\end{abstract}

Keywords: Lipoma; Spindle Cell Lipoma; Oral Cavity

\section{Introduction}

Lipomas are common benign neoplasms of adipose tissue. In the oral region they are uncommon and comprise $4 \%$ $5 \%$ of all tumors. Intra-oral lipomas have been described in the buccal mucosa, tongue, floor of mouth, vestibule, lip, palate, and gingiva [1]. Histologically, oral lipoma can be classified as classic lipoma or one of its variants, such as fibrolipoma, spindle cell lipoma, angiolipoma, salivary gland lipoma, pleomorphic lipoma, or atypical lipoma [2].

Spindle cell lipoma (SCL) is an uncommon variant, originally described in 1975 by Enzinger and Harvey [3]. Several examples have since been reported. Oral SCL is considered rare. The relative incidence of oral SCL is thought to be about $7 \%$, ranging between $2.17 \%$ and $9.8 \%$ of all oral lipomas [1,4-6]. These reviews, however, are not specific enough and do not provide detailed information regarding the clinico-pathologic characteristics

\footnotetext{
${ }^{*}$ There are no conflicts of interest to declare.

${ }^{\#}$ Corresponding author.
}

of oral SCL.

Here we describe the clinico-pathologic features of oral SCL, based on 35 cases, of which 2 cases are from our clinic and 33 cases are from the literature.

\section{Patients and Methods}

\subsection{Case 1}

A 45-year-old male patient was examined for a painless mass of the tongue that had been present for 12 months. The previous medical history was non-contributory. Intraoral examination revealed an elongated exophitic mass, $1.5 \mathrm{~cm}$, affecting the ventral side of the tongue, covered by normal appearing mucosa (Figure 1(a)). A provisional clinical diagnosis of oral lipoma was made. The lesion was removed under local anesthesia. Microscopically, mature adipocytes and spindle fibroblast-like cells were present and immersed in a myxoid stroma. No mitoses were present (Figure 1(b)). The spindle cells show negativity to S-100, Factor VIII, alpha-smooth muscle actin, cytokeratin and actin, and immuno-reactivity to 
CD34 (Figure 1(c)). The definitive diagnosis was SCL. No recurrences were observed after 2 years of follow-up.

\subsection{Case 2}

A 43-year-old male patient presented with an asympto-

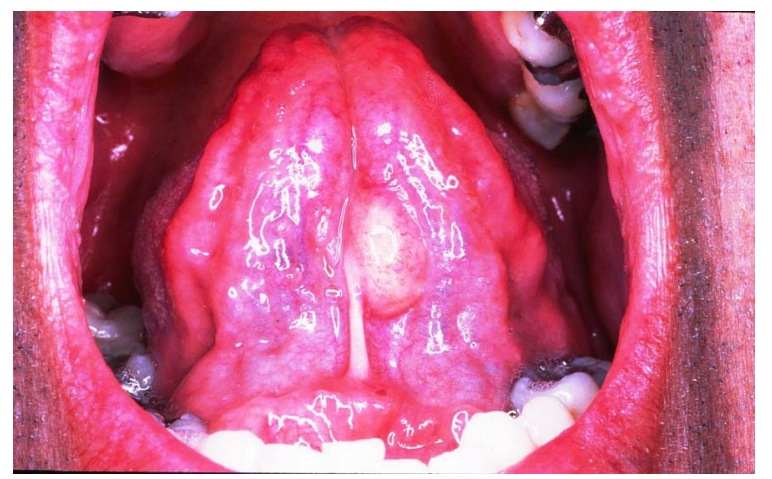

(a)

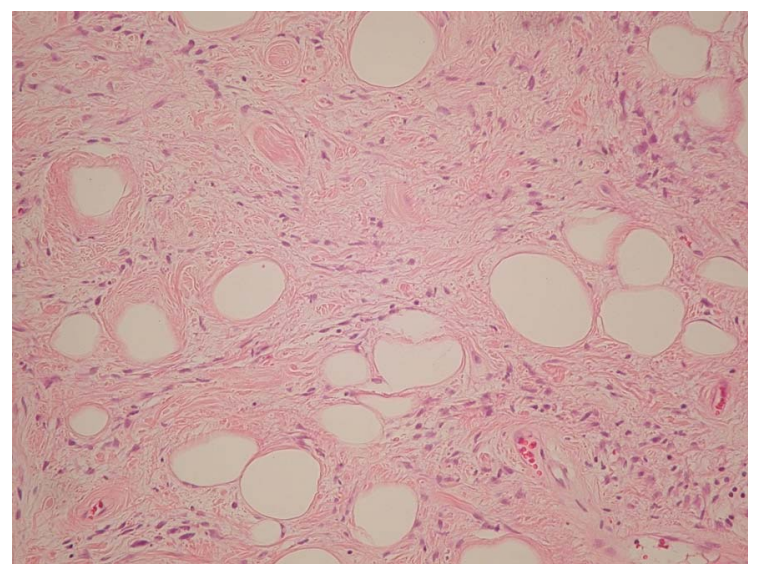

(b)

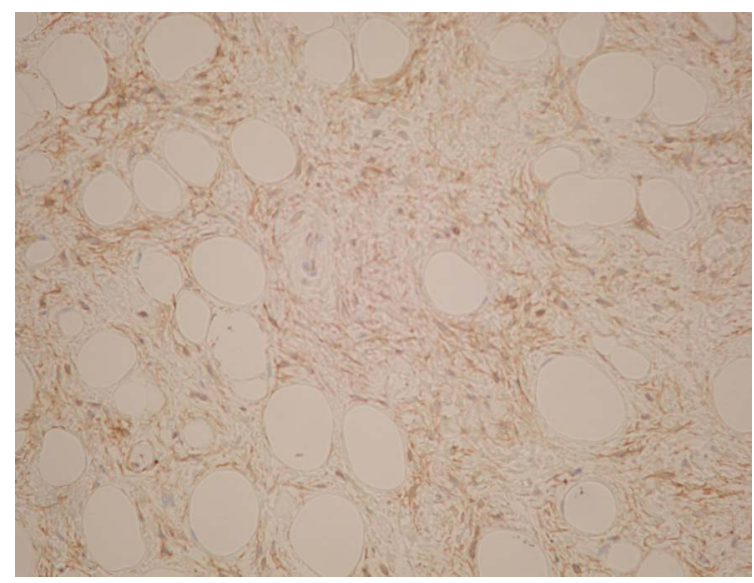

(c)

Figure 1. Spindle cell lipoma of the tongue affecting a 45year-old man. (a) Clinical view-an elongated exophitic mass affecting the ventral side of the oral tongue. (b) Adult fat cells and small, uniform spindle cells are present in a myxoid stroma $(H \& E \times 200)$. (c) The spindle cells show immuno-reactivity to CD34 (CD34 × 200). matic mass of the buccal mucosa that had been slowly increasing in size for about 5 years. The previous medical history was non-contributory. The extra-oral examination was normal. An intra-oral examination revealed a well-circumscribed, sessile lesion, on the left cheek, which was covered by healthy mucosa. The lesion had a firm consistency and measured $2.5 \times 1.5 \mathrm{~cm}$ (Figure 2). A clinical diagnosis of oral lipoma was made. The lesion was removed under general anesthesia. Microscopically mature adipocytes and spindle fibroblast-like cells were present and immersed in a myxoid stroma. No mitoses were present. The spindle cells show negativity to S-100, Factor VIII, alpha-smooth muscle actin, cytokeratin and actin, and immuno-reactivity to CD34. The definitive diagnosis was SCL. No recurrences were observed after 3 years of follow-up.

A literature search was performed of all well-documented SCL cases published between 1984 and 2012. Data regarding age, sex, oral site, size, histopathology, treatment, and follow up were recorded. Several publications, including large and valuable series on oral lipomas were excluded $[1,2,6]$ due to inadequate documentation of clinical and/or microscopic features of the reported cases.

\section{Results}

The clinico-pathologic features of the group of 35 cases (2 our cases and 33 from literature) of oral SCL are shown in Table 1 [6-29]. The patients, 23 men and 12 women $(\mathrm{M}: \mathrm{F}=1.92)$, had ages ranging from 23 to 88 years (mean: 55.0 years). The painless lesions were at the following oral sites: tongue $(\mathrm{n}=13)$, cheek/buccal mucosa $(n=11)$, floor of mouth $(n=5)$, lip $(n=2)$, hard palate $(n=2)$, alveolar ridge $(n=1)$, and maxilla $(n=1)$. All tumors were circumscribed, and ranged in size from 3 to $50 \mathrm{~mm}$ (mean: $20.87 \mathrm{~mm}$ ). Thirty-three cases (94\%) presented with a single lesion, whereas in two cases (6\%)

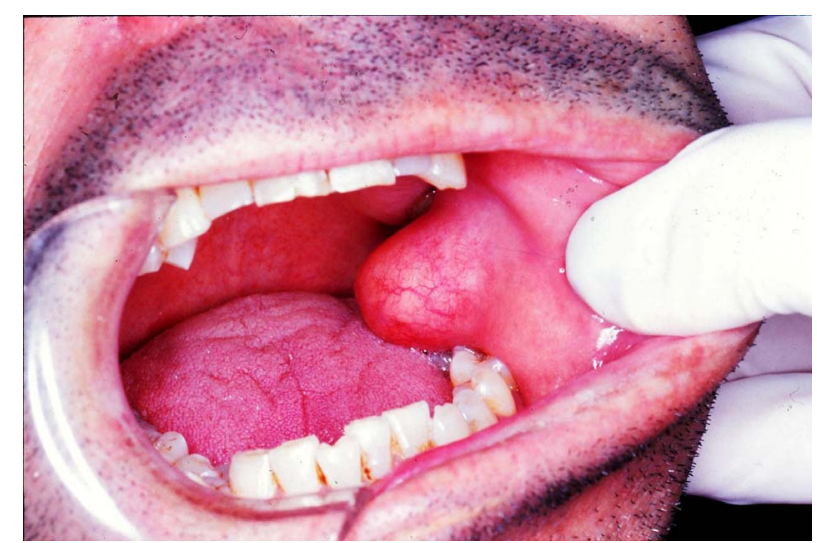

Figure 2. Spindle cell lipoma of the buccal vestibule affecting a 43-year-old man. Clinical view-an exophitic, sessile mass, affecting the left cheek, covered by healthy mucosa. 
affecting the tongue multiple SCL lesions were found. Thirty-four (97\%) were soft tissue lesions and one case (3\%) was intra-osseous. All the lesions were composed of a combination of mature adipocytes and spindle cells. The spindle cells were strongly immunoreactive for CD34, whereas the adipocytes were negative for this endothelial marker. In some cases, the adipocytes had decreased cytoplasmic lipid, which gave a pseudo-lipoblastic appearance to some of the adipocytes. None of the tumors had true lipoblasts or the hyperchromatic nuclei of atypical lipoma/well-differentiated liposarcoma.

Follow-up information was available for 20 cases. Mean follow-up was 2.72 years (range $0.7-5$ years).
One of the patients had a local recurrence.

\section{Discussion}

The most common oral site for SCL is the tongue (37\%), followed by the cheek/buccal mucosa (31\%), and floor of the mouth (15\%), but other locations such as the, lip, hard palate, alveolar ridge, and maxilla have also been reported (Table 1). Intra-osseous oral lipoma was reported to affect the maxilla and the mandible [30]. There is only one report on intra-osseous SCL affecting the maxilla [27]. The exact reason for the rarity of the intraosseous lipomas is still unknown.

Table 1. Reported cases of oral spindle cell lipoma $(n=35)$.

\begin{tabular}{|c|c|c|c|c|c|}
\hline Author/year & Age (years) & Sex & Location & Size $(\mathrm{mm})$ & Follow-up (years) \\
\hline McDaniel et al. 1984 [7] & $\begin{array}{l}33 \\
52\end{array}$ & $\begin{array}{l}\mathrm{F} \\
\mathrm{M}\end{array}$ & Floor of mouth tongue & 10 & $\begin{array}{l}2 \\
8\end{array}$ \\
\hline Christopoulos et al. 1989 [8] & 58 & M & Hard palate & 20 & 2 \\
\hline Levy \& Goding 1989 [9] & 74 & $\mathrm{~F}$ & Floor of mouth & 45 & -- \\
\hline Lombardy \& Odell 1994 [10] & 68 & $\mathrm{~F}$ & Tongue & 15 & -- \\
\hline Tosios et al. 1995 [11] & 55 & M & Cheek & 40 & 2 \\
\hline Khoo \& Lian 1995 [12] & 23 & $\mathrm{M}$ & Cheek & 50 & -- \\
\hline Piatteli et al. 1999 [13] & 75 & M & Cheek & 20 & -- \\
\hline Dutt et al. 1999 [14] & 42 & $\mathrm{~F}$ & Tongue & 30 & -- \\
\hline Piatteli et al. 2000 [15] & 63 & $\mathrm{M}$ & Cheek & 25 & 6 \\
\hline Agoff et al. 2001 [16] & 61 & $\mathrm{~F}$ & Buccal vestibule & & \\
\hline Said-Al-Naief et al. 2001 [17] & $\begin{array}{l}66 \\
53\end{array}$ & $\begin{array}{c}\mathrm{M} \\
\mathrm{F}\end{array}$ & Tongue tongue & $\begin{array}{c}30 \\
7\end{array}$ & $\begin{array}{l}1 \\
3\end{array}$ \\
\hline Darling et al. 2002 [18] & 69 & M & Alveolar ridge & 5 & 2 \\
\hline Atik et al. 2002 [19] & 45 & $\mathrm{M}$ & Tongue & 20 & \\
\hline Kaku et al. 2003 [20] & 75 & M & Tongue & 30 & \\
\hline Piatteli et al. 2005 [21] & 50 & M & Floor of mouth & 10 & 3 \\
\hline Kawasaki et al. 2006 [22] & 42 & $\mathrm{~F}$ & Cheek & 50 & -- \\
\hline Coimbra et al. 2006 [23] & 29 & $\mathrm{~F}$ & Floor of mouth & 15 & 3 \\
\hline Billings et al. 2006 [24] & $\begin{array}{l}55 \\
84 \\
88 \\
45 \\
67 \\
31 \\
75\end{array}$ & $\begin{array}{l}\mathrm{F} \\
\mathrm{F} \\
\mathrm{M} \\
\mathrm{M} \\
\mathrm{M} \\
\mathrm{F} \\
\mathrm{F}\end{array}$ & $\begin{array}{l}\text { Lower lip } \\
\text { Floor of mouth } \\
\text { Buccal mucosa } \\
\text { Tongue } \\
\text { Tongue } \\
\text { Tongue } \\
\text { Tongue }\end{array}$ & $\begin{array}{c}6 \\
10 \\
10 \\
9 \\
10 \\
3 \\
5\end{array}$ & $\begin{array}{c}1 \\
2 \\
4 \\
2.25 \\
1.5\end{array}$ \\
\hline Imai et al. 2008 [25] & 72 & $\mathrm{M}$ & Tongue & 15 & 1 \\
\hline Veccio et al. 2009 [26] & 72 & $\mathrm{M}$ & Cheek & 25 & \\
\hline Stokes et al. 2011 [27] & 35 & M & Maxilla & 15 & 0.7 \\
\hline Manor et al. 2011 [6] & 23 & $\mathrm{M}$ & Upper lip & 24 & 5 \\
\hline \multirow[t]{2}{*}{ Caldeira et al. 2011 [28] } & 38 & M & Cheek & 50 & \\
\hline & 60 & M & Hard palate & 23 & \\
\hline Chandrashekahar et al. 2012 [29] & 58 & $\mathrm{M}$ & Buccal mucosa & & \\
\hline Present case 2012 & 45 & M & Tongue & 15 & 2 \\
\hline Present case 2012 & 43 & $\mathrm{M}$ & Buccal mucosa & 25 & 1 \\
\hline
\end{tabular}


The average size of oral SCL $(20.87 \mathrm{~mm})$ is smaller compared to the extra-oral lesions $(46 \mathrm{~mm})$ [3]. The smaller size of the oral SCLs possibly reflects the greater sensitivity of the oral cavity to symptoms of an exophitic mass, and consequently are detected earlier than those in other anatomical sites. Similar to the extra-oral lesions, most oral SCLs were solitary lesions with multiple lesions being found in only two cases affecting the tongue $[20,25]$. The male predominance found in oral SCL is weaker compared to that reported in the extra-oral lesions, which are almost exclusively in males [3,31]. The exact reason for the sex predilection is still unknown.

The histopathology of the oral SCL is similar to its extra-oral counterpart. It is characterized by the presence of an admixture of mature fat cells, uniform spindle cells, and short bundles of collagen associated with spindle cells. It is suggested that spindle cells are analogous to the nonlipoblastic stellate mesenchymal cells of the primitive fat lobules, which have lost their ability to differentiate to lipocytes but are capable of collagen synthesis. The presence of mature lipocytes and fibroblastic cells in SCL probably reflects the potential of tumor cells to differentiate to both fat-storing and collagen-producing cells [10]. SCLs with floret-like multinucleated cells are classified as pleomorphic lipoma [2].

The immuno-reactivity for CD34 in the spindle cell component can be helpful in confirmation of the diagnosis; as CD34 can rarely be seen in well-differentiated liposarcoma, it can prevent the misdiagnosis of SCL as liposarcoma.

SCL, dermatofibrosarcoma protuberans and solitary fibrous tumor are CD34+ spindle cell tumors that may exhibit histopathologic and immunophenotypic overlap. However, careful evaluation of histopathologic features enables reliable distinction between these tumors [32]. The strong expression of $\mathrm{Bcl}-2$ observed in extra-oral SCL as well as in oral SCL, but not in nodular fasciitis, fibromatosis, dermatofibroma as well as in benign and malignant smooth muscle proliferations, may be of aid for differential diagnosis [20,33].

The reported cytogenetic analysis of adipose tissue tumors has shown that the various histopathologic subtypes are characterized by distinctive clonal chromosomal abnormalities. The most frequent translocation is $t(3 ; 12)(q 27-q 28 ; q 13-q 15)$, seen in almost $25 \%$ of lipomas. It has been shown that while classic lipomas typically harbor abnormalities involving 12q13-15, 6p, or 13q, spindle cell and pleomorphic lipomas typically display monosomy or partial loss of either or both of chromosomes 13 (13q12 and 13q14-q22) and 16 (16q13-qter) [34].

The differential diagnosis of SCL to be considered is dermatofibrosarcoma protuberans, nodular fascitis, angiomyofibroma, neurofibroma, and lipoma-like or my- xoid liposarcoma. Since the criteria established for diagnosis of liposarcoma of soft tissue are used for the diagnosis of intra-oral liposarcoma, the same criteria can be applied in differentiation of SCL and liposarcoma in the oral cavity [35].

The distinction between lipoma-like and myxoid liposarcoma is based on superficial location, clear demarcation and uniformity of spindle cells with bland nuclei, and the absence of classic lipoblastic and mitotic figures.

The best treatment for symptomatic SCL is complete surgical excision; however, this may lead to cosmetic or functional disorders in cases of large solitary or multiple lesions. In a recent report, the use of injection with phosphatidylchloline to induce lipolysis and reduce tumor volume was seen to be an effective therapeutic option [36].

No clear case of malignant transformation of SCL has been reported to date. Generally, solitary oral SCL shows no features of local recurrence after total excision. Only one case of recurrence has been reported, most probably due to incomplete excision [14]. In multiple involvements, consideration should be given to the possibility of sequential and multi-centric development of lesions over several years. Long-term follow up is necessary.

\section{Conclusion}

Oral SCLs appear not to differ from their extra-oral counterpart, which is much more common and larger in size. In both, recurrences are rare and the histological signs of malignancy are lacking.

\section{REFERENCES}

[1] E. R. Fregnani, F. R. Pires, R. Falzoni, et al., "Lipomas of the Oral Cavity: Clinical Findings, Histological Classification and Proliferative Activity of 46 Cases," International Journal of Oral and Maxillofacial Surgery, Vol. 32, No. 1, 2003, pp. 49-53. doi:10.1054/ijom.2002.0317

[2] M. A. Furlong, J. C. Fanburg-Smith and E. L. B. Childers, "Lipoma of the Oral and Maxillofacial Region: Site and Sub-Classification of 125 Cases,” Oral Surgery Oral Medicine Oral Pathology Oral Radiology and Endodontology, Vol. 98, No. 4, 2004, pp. 441-450. doi:10.1016/j.tripleo.2004.02.071

[3] F. M. Enzinger and D. A. Harvey, "Spindle Cell Lipoma,” Cancer, Vol. 36, No. 5, 1975, pp. 1852-1859.

[4] M. A. de Freitas, V. S. Freitas, A. A. de Lima, et al., "Intraoral Lipomas: A Study of 26 Cases in a Brazilian Population," Quintessence International, Vol. 40, No. 1, 2009, pp. 79-85.

[5] L. E. R. Julliasse, C. F. W. Nonaka, L. P. Pinto, et al., "Lipomas of the Oral Cavity: Clinical and Histopathologic Study of 41 Cases in a Brazilian Population,” European Archives of Otorhinolaryngology, Vol. 267, No. 3, 2010, pp. 459-465. 
[6] E. Manor, N. Sion-Vardy, B. Z. Joshua, et al., "Oral Lipoma: Analysis of 58 New Cases and Review of the Literature,” Annals of Diagnostic Pathology, Vol. 15, No. 4, 2011, pp. 257-261.

doi:10.1016/j.anndiagpath.2011.01.003

[7] R. K. McDaniel, J. R. Newland and D. G. Chiles, "Intraoral Spindle Cell Lipoma: Case Report with Correlated Light and Electron Microscopy," Oral Surgery Oral Pathology Oral Radiology and Endodontology, Vol. 57, No. 1, 1984, pp. 52-57. doi:10.1016/0030-4220(84)90260-3

[8] P. Christpoulos, O. Nicolatou and A. Partikiou, "Oral Spindle Cell Lipoma: Report of a Case,” International Journal of Oral and Maxillofacial Surgery, Vol. 18, No. 4, 1989, pp. 208-209. doi:10.1016/S0901-5027(89)80054-2

[9] F. E. Levy and G. S. Goding Jr., "Spindle Cell Lipoma: An Unusual Oral Presentation," Otolaryngology-Head and Neck Surgery, Vol. 101, No. 5, 1989, pp. 601-603.

[10] T. Lombardi and E. W. Odell, "Spindle Cell Lipoma of the Oral Cavity: Report of a Case," Journal of Oral Pathology \& Medicine, Vol. 23, No. 5, 1994, pp. 237-239.

[11] K. Tosios, S. I. Papanicolaoi, N. Kapranos and N. Papadogeorgakis, "Spindle Cell Lipoma of the Oral Cavity," International Journal of Oral and Maxillofacial Surgery, Vol. 24, No. 5, 1995, pp. 363-364. doi:10.1016/S0901-5027(05)80493-X

[12] S. P. Khoo and C. B. Lian, "Intraoral Spindle Cell Lipoma: Report of a Case and Literature Review," Annals of Dentistry, Vol. 54, No. 1-2, 1995, pp. 53-55.

[13] A. Piatteli, C. Rubini, M. Fioroni, et al., "Spindle-Cell Lipoma of the Cheek: A Case Report," Oral Oncology, Vol. 36, No. 5, 2000, pp. 495-496. doi:10.1016/S1368-8375(00)00035-X

[14] S. N. Dutt, D. M. East, Y. Saleen, et al., "Spindle-Cell Variant of Intralingual Lipoma-Report of a Case with Literature Review," Journal of Laryngology and Otology, Vol. 113, No. 6, 1999, pp. 587-589. doi:10.1017/S0022215100144561

[15] A. Piatteli, M. Fioroni and C. Rubini, "Spindle Cell Lipoma of the Oral Cavity: Report of a Case," Journal of Oral and Maxillofacial Surgery, Vol. 57, No. 5, 1999, pp. 624-625.

[16] S. N. Agoff, A. L. Folpe, V. S. Greico, et al., "Spindle Cell Lipoma of the Oral Cavity. Report of a Rare Intramuscular Case with Fine Needle Aspiration Findings,” Acta Cytologica, Vol. 45, No. 1, 2001, pp. 93-98.

[17] N. Said-Al-Naief, F. R. Zahurullah and J. J. Sciubba, “Oral Spindle Cell Lipoma,” Annals of Diagnostic Pathology, Vol. 5, No. 4, 2001, pp. 207-215. doi:10.1053/adpa.2001.26973,

[18] E. Atik, U. Usta and N. E. Aydin, "Pleomorphic Lipoma of the Tongue," Otolaryngology-Head and Neck Surgery, Vol. 126, No. 4, 2002, pp. 430-431.

[19] M. Darling, I. Thompson and J. Schneider, "Spindle Cell Lipoma of the Alveolar Mucosa: A Case Report," Oral Surgery Oral Medicine Oral Pathology Oral Radiology and Endodontology, Vol. 93, No. 2, 2002, pp. 171-173. doi:10.1067/moe.2002.120520,

[20] N. Kaku, K. Kashima, T. Daa, et al., "Multiple Spindle
Cell Lipomas of the Tongue: Report of a Case,” Apmis, Vol. 111, No. 5, 2003, pp. 581-585.

[21] A. Piatteli, V. Perrotti, M. Fioroni, et al., "Spindle Cell Lipoma of the Floor of the Mouth: Report of a Case," $\mathrm{Au}$ ris Nasus Larynx, Vol. 32, No. 2, 2005, pp. 205-207. doi:10.1016/j.anl.2005.01.013

[22] G. Kawasaki, S. Yanamto, K. Hirata, et al., "Spindle Cell Lipoma of the Cheek: A Case Report and Review of Literature,” Oral Oncology Extra, Vol. 42, No. 10, 2006, pp. 301-304. doi:10.1016/j.ooe.2006.09.003,

[23] F. Coimbra, J. M. Lopes, H. Figueiral, et al., "Spindle Cell Lipoma of the Floor of the Mouth: A Case Report," Medicina Oral Patologia Oral y Cirugia Bucal, Vol. 11, No. 5, 2006, pp. E401-403.

[24] S. D. Billings, J. D. Henely, D. J. Summerlin, et al., "Spindle Cell Lipoma of the Oral Cavity," American Journal of Dematopathology, Vol. 28, No. 1, 2006, pp. 28-31.

[25] T. Imai, M. Michizawa, H. Shimizu, et al., "Bilateral Multiple Spindle Cell Lipomas of the Tongue," Oral Surgery Oral Medicine Oral Pathology Oral Radiology and Endodontology, Vol. 106, No. 2, 2008, pp. 264-269.

[26] G. Vecchio, P. Amino, R. Catabrano, et al., "Spindle Cell/Pleomorphic Lipoma of the Oral Cavity,” Journal of Craniofacial Surgery, Vol. 20, No. 6, 2009, pp. 19921994.

[27] S. M. Stokes, J. P. Wood and J. T. Castle, "Maxillary Intraosseous Spindle Cell Lipoma," Journal of Oral and Maxillofacial Surgery, Vol. 69, No. 6, 2011, pp. e131e134.

[28] P. C. Caldiera, V. F. Bernardes and A. C. Miranda, "Oral Spindle Cell Lipomas,” Open Journal of Stomatology, Vol. 1, No. 4, 2011, pp. 202-206.

[29] P. Chandrashekar, M. Jose, M. Dadhich, et al., "Spindle Cell Lipoma: A Case Report and Review of Literature," Kathmandu University Medical Journal (KUMJ), Vol. 10, No. 2, 2012, pp. 92-95. doi: doi:10.3126/kumj.v10i2.7353

[30] S. Cakarer, F. Selvi, S. C. Isler, et al., "Intraosseous Lipoma of the Mandible: A Case Report and Review of the Literature," International Journal of Oral and Maxillofacial Surgery, Vol. 38, No. 8, 2009, pp. 900-902. doi:10.1016/j.ijom.2009.03.712

[31] C. D. M. Fletcher and E. Martin-Bates, "Spindle Cell Lipoma: A Clinicopathological Study with Some Original Observations,” Histopathology, Vol. 11, No. 8, 1987, pp. 803-817.

[32] L. Wood, T. J. Fountaine, L. Rosamilia, et al., "Cutaneous CD34+ Spindle Cell Neoplasms: Histopathologic Features Distinguish Spindle Cell Lipoma, Solitary Fibrous Tumor and Dermatofibrosarcoma Protuberans," American Journal of Dermatopathology, Vol. 32, No. 8, 2010, pp. 764-766.

[33] S. Suster, C. Fisher and C. A. Moran, "Expression of bcl-2 Oncoprotein in Benign and Malignant Spindle Cell Tumors of Soft Tissue, Skin, Serosal Surfaces and Gastrointestinal Tract," American Journal of Surgical Pathology, Vol. 22, No. 7, 1998, pp. 863-872.

[34] A. A. Sandberg, "Update on the Cytogenetics and Mole- 
cular Genetics of Bone and Soft Tissue Tumors: Lipoma," Cancer Genetics and Cytogenetics, Vol. 150, No. 2, 2004, pp. 93-114.

[35] J. C. Fanburg-Smith, M. A. Furlong and E. L. B. Childers, "Liposarcoma of the Oral and Salivary Gland Region: A Clinicopathologic Study of 18 Cases with Emphasis on Specific Sites, Morphologic Subtypes and Clinical Out- come," Modern Pathology, Vol. 15, No. 10, 2002, pp. 1020-1031.

[36] F. G. Bechara, M. Sand, D. Sand, et al., "Lipolysis of Lipomas in Patients with Familial Multiple Lipomatosis: An Ultrasonography-Controlled Trial,” Journal of Cutaneous Medicine and Surgery, Vol. 10, No. 4, 2006, pp. 155-159. 